DOI: $\underline{10.17805 / g g z .2020 .2 .4}$

\title{
Ключевые проблемы евроинтеграции Сербии на современном этапе
}

А. И. Филимонова

Московский гуманитарный университет

Статья представляет собой анализ принщипов и подходов Евросоюза к евроинтеграции «западно-балканских стран», прежде всего, Сербии, на фоне многоуровневых кризисных явлений на его пространстве во внешней и внутренней политике, экономике и соииальной сфере. Рассматриваются изменения в программных документах - две Стратегии безопасности (2003 и 2016 г2.), Стратегия расширения ЕС (февраль 2018 г.) и Солоникская декларация (май 2018 г.), новые модели и тенденщии взаимоотношений европейских стран после Брексита, роль и место представителей европейского истеблишмента относительно перспектив и условий дальнейшего расширения ЕС и проблемь сербской евроинтеграчии. Выявляется главное отличие предвступительных переговоров Евросоюза с Сербией от специфики заключенного Соглашения о стабилизачии и присоединении в аспекте проблемы Косово и Метохии.

Ключевые слова: Евросоюз; Сербия; европейская интеграция; проблема Косово и Метохии; Соглашение о стабилизачии и присоединении; «Западные Балканьл»

\section{Key Issues of Serbia's European Integration at the Present Stage}

A. I. Filimonova

Moscow University for the Humanities

The article analyzes the principles and approaches of the European Union to the European integration of the "Western Balkan countries", primarily Serbia, against the backdrop of multi-level crisis phenomena in its territory in foreign and domestic policy, economy and social sphere. The author considers changes in policy papers - two security strategies (2003 and 2016), the EU's Enlargement Strategy (February 2018) and the Thessaloniki Declaration (May 2018), new models and trends in relations between European countries after Brexit, the role and place of representatives of the European establishment regarding the prospects and conditions for further EU enlargement, and the issues of Serbia's European integration. The main difference between the EU's pre-accession negotiations with Serbia and the specifics of the concluded Agreement on stabilization and association in the aspect of the problem of Kosovo and Metohija is revealed. 
Keywords: European Union; Serbia; European integration; problem of Kosovo and Metohija; Agreement on stabilization and association; "Western Balkans"

\section{ВВЕДЕНИЕ}

Более чем скромные торжества, без особой радости и веселья прошедшие в Брюсселе в 2017 г. по поводу двадцатипятилетнего юбилея Маастрихтского договора, лишний раз доказали, что ЕС находится в состоянии глубокого финансового, социального, идеологического и, в целом, экзистенциального кризиса. Уличные протесты, безработица, политика «затягивания поясов», взрывной рост внешнего и внутреннего долга, мигранты из переферийных европейских, ближневосточных, африканских и других стран, «спящие ячейки» джихаддистов, теракты, диспропорция между севером и югом, городом и селом, «белая демографическая чума» коренного населения - все это стало обычными явлениями, вызывающими в общественной атмосфере состояние тревоги, неизвестности, безволия и апатии. Греция, Кипр, Испания, Ирландия, Португалия, Италия, Словения и даже Франция тонут в невиданных долгах и «мерах экономии». Снижение в перефирийных странах расходов на науку, образование и здравоохранение ведет их к отсталости и регрессу. Практически исчезло такое явление, как солидарность и единство ЕС, национальные тенденции усиливаются практически в каждой стране союза. Доверие к евроинститутам, бывшим некогда путеводной звездой, впервые в своей истории оказалось на максимально низком уровне. Кроме небольшой верхушки, точнее, брюссельской номенклатуры, состоянием дел в Евросоюзе не доволен никто (Јовановић, 2013: Электронный ресурс).

Разногласия между странами ЕС возникают практически по каждому мало-мальски значимому вопросу: монетарная и фискальная политика, деятельность банков, энергетическая политика, сжиженный газ, социальная политика, ГМО, отношения с Россией, проблема Косово и Метохии, Ирак, Ливия, Сирия, Иран, расширение ЕС и т. п.

Главными маркерами политической турбулентности стали:

- отрицательные ответы французов и голландцев в 2005 г. в ходе референдума о конституции ЕС;

- поставивший Грецию на грань выхода из еврозоны референдум 5 июля 2015 г.;

- разногласия по проблеме беженцев между Старой и Новой Европой;

- британское голосование 2016 г. о выходе из ЕС;

- провал попытки Маттео Ренци изменить конституцию в декабре 2016 $\Gamma$;

- торговая война с США; 
- категорическое нежелание дальнейшего расширения союза (запрет Франции в октябре 2019 г. на открытие предвступительных переговоров с Северной Македонией и Албанией) (там же).

В условиях столь изменчивых параметров глобального и регионального международно-политического контекста Евросоюз попытался определить raison d'être и ориентиры своего дальнейшего развития. На саммите Европейского Совета 28 июня 2016 г. была принята новая стратегия безопасности Европейского Союза под названием «Общее видение, единый подход: сильная Европа» ("Shared Vision, Common Action: A Stronger Europe”). Стратегия была сформирована в условиях, когда узловыми проблемными пунктами европейских стран являлись финансовый и миграционный кризис, предполагаемый выход Великобритании из ЕС (документ был подготовлен перед проведением британского референдума) и неопределенность внешней политики США в связи с приходом к власти Дональда Трампа. Европейские аналитики определили стратегию не просто как программный документ, а как «кодификацию стратегической ориентации», «часть идентичности ЕС», формирующей весь спектр внешних действий Евросоюза (Бископ, 2009: Электронный ресурс).

Следует отметить существенное отличие данной стратегии безопасности ЕС от предыдущей. Так, если результат существования Евросоюза в Европейской стратегии безопасности от 2003 г. под названием «Безопасная Европа в лучшем мире» (“А Secure Europe in a Better World”) определялся формулой «Никогда раньше Европа не была столь процветающей, безопасной и свободной как в наши дни», то стратегия 2016 г. фиксирует не только утрату перспективы, но и ценностный экзистенциальный кризис ЕС: «Цель и существование нашего союза ставится под вопрос» (цит. по: Толстухина, 2016: Электронный ресурс). Выявляются кризисные явления как внутреннего, так и внешнего характера, главными проблемами называются общая политика ЕС как единого субъекта мировой политики, удержание позиций в мировой экономике и безопасность.

Кроме того, следует выделить два ключевых отличия двух документов. Во-первых, в стратегии 2016 г. базовыми принципами глобальной и европейской безопасности провозглашаются «территориальная целостность, независимость государств и нерушимость границ», т. е. подтверждается приверженность Хельсинскому заключительному акту. Во-вторых, в стратегии 2016 г., в отличие от стратегии 2003 г., делается большой акцент на собственной безопасности стран ЕС, а не на абстрактной проблеме глобальной безопасности. По сути, речь идет о новом курсе Евросоюза на усиление внутреннего интеграционного акцента в военно-политической сфере вплоть до формирования «стратегической автономии». Это является логичным продолжением Гентской инициативы министров обороны стран ЕC 2011 г., направленной на пере- 
ориентацию ВПК на основе специализации каждой страны-члена ЕС. В практической сфере ставятся задачи создания подобия единого Генерального штаба (отражение амбиций германо-французского блока на создание полноформатной системы планирования, командования и боевого управления вооруженными силами), объединенного ВМФ и общей правоохранительной системы, а также снятии ряда ограничений внутри оборонного рынка, создание собственной оборонной индустрии, унификации экспорта вооружения Евросоюза и его согласование на наднациональном уровне (Глобальная стратегия ... , 2017: Электронный ресурс). Кроме того, констатируется необходимость доработки стратегии в аспекте безопасности в направлении сочетания «мягкой и жесткой силы» (Толстухина, 2016: Электронный ресурс).

В целом, несмотря на общий декларативный характер стратегии 2016 г. и во многом повторение прежних положений стратегии 2003 г., два данных аспекта указывают на преследование не отвлеченных идеалистических концепций, а принципа жесткого прагматизма в соблюдении собственных интересов ЕС. При этом, как совершенно справедливо отмечает С. Бископ, «на самом деле большинство членов Евросоюза уже не имеют национальных интересов, отличающихся от интересов других членов ЕС. Интересы слишком часто путают с вниманием: если Бельгия, например, уделяет больше внимания Центральной Африке, чем Кавказу, это не означает, что объективно она меньше заинтересована в стабилизации ситуации на Кавказе, чем, например, Польша, и наоборот» (Бископ, 2009: 110). Чтобы отстоять свой базовый интерес - быть субъектом, а не объектом мировой политики, - ЕС в приоритет ставит «внешнюю политику и политику обороны, обеспечение нерушимости собственного территориального пространства и формирование необходимых для этого силовых инструментов» (структурирование, координация и усиление взаимодействия военных потенциалов стран ЕС). Однако не следует трактовать эти меры как альтернативу или противовес Североатлантическому альянсу, пока они вписываются в концепцию «усиления опоры НАТО в Европе» (Глобальная стратегия ..., 2017: 10).

Таким образом, при сохранении приверженности прежней системе глобального управления и трансформации миропорядка ЕС ясно дает понять, что намеревается быть субъектом трансформации. В связи с этим происходит неизбежное столкновение между национальными интересами стран первого эшелона - т. н. G4 (Франция, Германия, Италия и Испания), стремящихся к более самостоятельной роли ЕС не только на региональном, но и на глобальном уровне, с учетом наднациональных трансатлантических целей союза. Действительно не может не поражать многоаспектность задачи выработки единого стратегического курса объединения, требующего согласования (или подавления) всех наслоений и переплетений национальных подходов, равно как 
попытки ЕС создать институциональную и функциональную основу для усиления собственных позиций, фигурально выражаясь, определить угол самостоятельного дрейфа, не выходя из атлантического течения, являются примечательными, но труднореализуемыми.

Одним из проявлений «самостоятельного дрейфа» к двусторонним, а не мультинациональным договоренностям стало заключение в декабре 2017 г. Соглашения об обороне между Британией и Польшей. Оно предусматривает сотрудничество в области поставок вооружения, проведение совместных военных учений, обмен разведывательной информацией, координацию информационной политики, общую борьбу «с российской дезинформацией» (на эти цели Лондон предоставил Варшаве 5 млн фунтов стерлингов, последняя ведет пропаганду и на белорусском языке). При этом в отношении католической Польши ранее была предпринята «европейская гармонизация», т. е. весьма суровые меры, вплоть до угроз ввести санкции, лишить права голоса в ЕС на основе ст. 7 Лиссабонского договора и урезать финансирование из бюджета ЕС. Брюссельская бюрократия вменила в вину Польше попытки усилить контроль над судебной системой, отказ принимать мигрантов из мусульманских стран, увеличение контроля государства над СМИ, намерение ограничить деятельность иностранных медиа, а также запрет на аборты кроме исключительных случаев (Јовановић, 2018: Электронный ресурс). Попытки Варшавы проложить путь к укреплению суверенности в наднациональном союзе были пресечены в корне, национальными и государственными интересами Польше пришлось пожертвовать. При этом не был поставлен вопрос Ангеле Меркель, самоинициативно пригласившей мигрантов из стран Ближнего Востока и Северной Африки в Европу и предложившей всему Евросоюзу разделить это «гостеприимное бремя», о законности подобной меры. Легитимные шаги Польши, касающиеся исключительно внутренних мер, были пресечены на корню, в то время как нелегитимные внезапные, волюнтаристские, несущие очевидную угрозу безопасности и культурно-исторической идентичности европейских народов инициативы А. Меркель стали императивом.

В январе 2018 г. получило развитие британско-французское Ланкастерское соглашение от 2010 г., создающее единый оборонный рынок, единую военную инфраструктуру и направленное на усиление взаимодействия ВМС и ВВС. Соглашение 2018 г. конкретизируется совместными действиями флотов в Атлантике, особенно в проливе Ла-Манш, предусматривает более тесное взаимодействие ПВО, а также формирование сводного 10-тысячного экспедиционного корпуса для действий в любой точке земного шара. Так Британия, выходящая из союза, закладывает основы реализации своих интересов на отдельных направлениях, в качестве противодействия Германии «отрывает» Польшу 
и Францию, цементируя их «привязанность» конкретными военными обязательствами.

В продолжение тенденции со своей стороны канцлер Германии Ангела Меркель и президент Франции Эммануэль Макрон 22 января 2019 г. подписали Аахенское соглашение о сотрудничестве двух стран, которое предусматривает создание франко-германской экономической зоны, координацию международной и информационной политики, деятельности спецслужб, оборонного экспорта и функционирования ВПК в рамках общей стратегии оборонной и военно-промышленной политики. В Аахенском соглашении, как это ни поразительно выглядит, учитывая существование Устава ООН, прямо запрещающего подобные действия, упоминаются усилия Франции, которые она предпримет для предоставления Германии статуса постоянного члена Совета Безопасности ООН (!). Аахенским соглашением, как констатирует российский эксперт Владислав Гулевич, «Париж и Берлин формируют “Европу двух скоростей”, в которой они намерены стать лидерами» (Гулевич, 2019: Электронный ресурс).

В отношении «других стран», что имеет первостепенное значение для Сербии, в стратегии 2016 г. всего-навсего провозглашался неопределенный принцип «устойчивости» и «принипиального прагматизма», что означает «желание и способность к реформам...» (Глобальная стратегия ..., 2017: 4). Сама идея о вступлении стран «Западных Балкан» в ЕС проистекает из повестки дня, принятой на саммите в Салониках в конце июня 2003 г. Тогда ЕС находился на пике расширения - в преддверии вступления 10 стран бывшего Восточного блока и, казалось, нет ничего естественнее, чем последующее присоединение балканских стран. Однако уже в 2004 г. начались серьезные трудности с Грецией, в 2005 г. грянул провал референдумов во Франции и Нидерландах, в 2008 г. последовал финансовый кризис, потрясший еврозону, наконец, провозглашение террористами Армии освобождения Косово независимости «Республики Косово». В попытках выработки экономических и политических антикризисных механизмов Евросоюз пошел по авторитарному пути. Однако этот путь оказался неэффективным, что продемонстрировал мигрантский кризис 2015 г., выливший не реки, а целые моря беженцев из стран Ближнего и Среднего Востока. В итоге в политической платформе о будущем ЕС «Белая книга. Будущее Европы» ("The White Paper on the Future of Europe - Reflections and Scenarios for the EU27 by 2025") понятие «расширение» не упоминается (Јовановић, 2018: Электронный ресурс). Не будет преувеличением сказать, что в ближайшее десятилетие не только не произойдет расширения ЕС, но сомнительно и само существование объединения в привычном виде. Так внутренние и внешние кризисные явления положили конец «европейским иллюзиям». 
Сербия провозгласила курс на вступление в ЕС еще до 2003 г. - после свержения С. Милошевича в ходе «цветной революции» 5 октября 2000 г. В ноябре 2000 г. было подписано Рамочное соглашение ЕС с Союзной Республикой Югославией, по которому обеспечивалась экономическая помощь Евросоюза политическим и экономическим реформам. Уже тогда особый акцент ставился на «региональном сотрудничестве». Переговоры о заключении Соглашения о стабилизации и присоединении (ССП) начались в ноябре 2005 г. Сербия и Черногория, тогда составляющие государственный союз, получили в 2005 г. одобрение в виде позитивной оценки целесообразности (feasibility study), но лишь после того, как выдали в Гаагу 14 генералов. Но сразу же последовала и «желтая карточка» в виде предупреждения, что сотрудничества недостаточно, пока «в бегах» остаются Ратко Младич и Радован Караджич. Однако 3 июня 2006 г. в Черногории был проведен референдум, и она вышла из состава СРЮ, Сербия стала правопреемницей бывшего общего государства, к которой ЕС стал весьма настороженно относиться. Каждый ее шаг в направлении евроинтеграции оценивался с точки зрения кооперативности с Международным трибуналом по бывшей Югославии (МТБЮ). После выдачи генералов Здравко Толимира и Властимира Джорджевича ЕС сменил гнев на милость. Тогда Брюссель вел переговоры о расширении с Хорватией и Турцией, относительно «Западных Балкан» упоминалась лишь «европейская перспектива», что означало наличие шанса вступления в ЕС, но не обещание вступления в «евроклуб». В докладе от 2007 г. Комиссия указывала, что данная перспектива включает возможность вступления в ЕС «тогда, когда будут выполнены все необходимые для этого условия». Однако сами условия не перечислялись. Далее отмечались «строгие, но справедливые условия», при этом также определение «справедливые» не объяснялось (Jovanović, 2007: Электронный ресурс). Таким образом, в коллизии о расширении ЕС неизменно происходило столкновение двух принципов: с одной стороны, подчеркивалась официальная политика «прогресса в соответствии с заслугами», которая утверждает, что страна будет приближаться к членству исключительно в зависимости от удовлетворения Копенгагенским критериям. С другой стороны, существует «тактическая политика», приближающая к Брюсселю страну в зависимости от соответствия ее неким иным геополитическим или политическим потребностям ЕС, не имеющим никакой связи с Копенгагенскими критериями.

\section{СОГЛАШЕНИЕ О СТАБИЛИЗАЦИИ И ПРИСОЕДИНЕНИИ}

29 апреле 2008 г. при президенте Борисе Тадиче Сербия заключила ССП, ЕС его ратифицировал в 2010 г., в силу соглашение вступило лишь 1 сентября 2013 г. после ратификации последним членом - Литвой и уже при других 
политиках у власти в Белграде. Одновременно было заключено и Временное торговое соглашение (ВТС). Однако до начала процедуры ратификации на основе предложения Нидерландов Европейский совет принимает решение не начинать практическое применение ВТС (подписание должно было состояться 1 июля 2008 г.) с Сербией пока та не осуществит полное сотрудничество с МТБЮ. Тем самым была создана беспрецедентная внеправовая ситуация, когда международный договор подписан, но не может быть применен, поскольку Европейский совет его блокировал, поставив незаконное условие. Тогда сербская власть принимает также беспрецедентное решение об одностороннем применении ВТС с 1 января 2009 г. (что нанесло серьезный ущерб экономике Сербии), в то время как Брюссель пошел на ответную меру с 7 декабря 2009 г., в силу ВТС вступило 1 февраля 2010 г. 1 марта 2012 г., в преддверии майских президентских и парламентских выборов в Сербии, Европейский совет принял решение о присвоении Сербии статуса страны-кандидата.

Сербская власть, после выборов 2012 г. бессменно сконцентрированная в руках нынешнего президента Александра Вучича, по-прежнему проходит процедуру предвступительной подготовки. Сразу отметим, что в случае Сербии и ее евроинтеграции речь идет об определенном историческом парадоксе: сербскую политику «европейского фундаментализма» возглавляют политические силы (Сербская прогрессивная партия Александра Вучича, бывшего генерального секретаря Сербской радикальной партии Воислава Шешеля), выстроившие свою политическую идентичность на антиевропейской, антиглобалистской и пророссийской ориентации (Јовановић, 2018: Электронный ресурс). Поворот произошел во второй половине 2008 г., когда от Сербской радикальной партии откололось крыло, взявшее название Сербская прогрессивная партия, во главе с Томиславом Николичем и Александром Вучичем (последний, занимая разные правительственные посты, практически сразу же сконцентрировал реальную власть в своих руках). Новая партия пережила трансформацию в прозападном направлении, однако была вынуждена балансировать между Западом и Россией в связи со спецификой своего избирательного корпуса, не потерявшего антизападную, антиглобалистскую и, главное, русофильскую составляющую.

Предвступительная процедура заключается в том, что страна-кандидат ведет переговоры о вступлении в ЕС с Европейской комиссией. Переговоры включают 35 глав, посвященных политическим, экономическим, правовым и другим вопросам. Европейская комиссия самостоятельно вырабатывает предложение Совету министров, который принимает решение или, в случае необходимости, вместе с Европейским парламентом вносит коррективы. Итоговое решение возвращается Европейской комиссии для исполнения. Таким образом, Европейская комиссия не придерживается принципа разделения власти, 
она является уникальным органом, который сам вырабатывает, исполняет решения и рассматривает спорные вопросы. Переговоры о вступлении в ЕС это длительный процесс, состоящий из открытия и закрытия каждой главы переговоров отдельно (всего 35 глав). При этом согласие каждой страны ЕС требуется и на открытие, и на закрытие каждой главы. Нехитрый подсчет показывает, что $35 \times 2 \times 27=1890$. Столько гипотетических препятствий может быть воздвигнуто на пути к «единственной стратегической цели». Весьма примечательно и то, что в случае Сербии переговорный процесс начат с самых сложных глав - это региональная политика (признание независимости Косово) и изменение конституции, хотя при вступлении других стран самые тяжелые для них условия были конечными шагами интеграции (Jovanović, 2007: Электронный ресурс). В связи с этим, как заключает сербский исследователь Мирослав Йованович, «у ЕС более чем широкое право выбирать кого, какого, как и когда принимать в свои ряды» (Јовановић, 2009: Электронный ресурс; здесь и далее пер. наш. - $A$. Ф.).

\section{ССП И КОСОВСКАЯ ПРОБЛЕМА}

Относительно проблемы Косово и Метохии отметим главное: Соглашение о стабилизации и присоединении не рассматривает этот сербский автономный край как составную часть Сербии (ст. 15, ст. 135). Глава 3 «Сотрудничество Сербии с другими государствами региона» в ст. 15 пп. 4, 5 указывает: Сербия начнет переговоры с государствами, подписавшими свои ССП до и после Сербии. Ст. 135 п. 2 гласит: «Это соглашение не применимо на территории Косова». ССП заключается со стороны ЕС только с независимыми государствами, однако из-за пяти членов ЕС, не признавших Косово, его статус не определяется прямо. «Республика Косово» свое собственное ССП заключила с ЕС в 2015 г. Следовательно, существует международное обязательство Сербии следовать положениям ССП. Заключенное И. Дачичем и А. Вучичем Брюссельское соглашение (апрель 2013 г.) говорит том, что власть Сербии по собственной воле в отсутствие прямой военной или иной угрозы отказалась от полиции, суда и системы безопасности Республики Сербии на территории Косова и Метохии, включая север (Први споразум ..., 2013: Электронный ресурс). Север Косова и Метохии (общины Лепосавич, Зубин Поток, Звечан и Северная Косовска-Митровица) в подавляющем большинстве с сербским населением до этого момента был абсолютно недоступен сепаратистской Приштине. Во всем тексте Брюссельского соглашения нет ни единого упоминания Резолюции Совета Безопасности ООН 1244, Конституции и законов Республики Сербии, нет ни в каком виде упоминания о том, что Косово и Метохия являются составной частью Республики Сербия. Есть только упоминание «косовских законов», а центральные органы власти находятся в 
Приштине. Тем самым со стороны Сербии признается законность конституционно-правового порядка «Республики Косово». При всей правовой и политической абсурдности не следует рассматривать Брюссельское соглашение как случайный волюнтаристский акт Белграда. Брюссельское соглашение было призвано упорядочить аспекты взаимоотношений Белграда и Приштины до заключения соглашения, которое урегулирует все сегменты взаимоотношений между Сербией и Косово. Таким образом, тезисы официального Белграда «Мы никогда не признаем независимость Косово» и «Наша цель - ЕС» (Јовановић, 2013: Электронный ресурс) являются взаимоисключающими. Ратификация ССП, выполненная при А. Вучиче, накладывает международные обязательства, следовательно, ради обеспечения конституционной обязанности - сохранения территориальной целостности и суверенитета страны - Сербия должна выйти из этого соглашения. В противном случае невнятные обвинения в «давлении Запада по поводу признания независимости Косово» не являются легитимными. Отметим также, что ССП по сути является ограничением права сербского государства на проведение независимой внешней и внутренней политики, это эффективный политический инструмент, функционирующий путем обязательств, вытекающих из положений соглашения. При этом обязательства действуют даже в том случае, если страна никогда не вступит в ЕС. ЕС и Запад в целом видят в ССП весьма действенное средство влияния, позволяющее превратить переговорный процесс о евроинтеграции для Сербии в перманентное выполнение условий западных стран.

Отметим еще один весьма примечательный момент. На выполнении Сербией на пути евроинтеграции «всех условий» особенно настаивает Великобритания, сама сбрасывающая ЕС как ненужный балласт. 31 октября 2019 г. посол Великобритании в Сербии Шан Маклеод (Sian MacLeod) заявила, что правительство Великобритании «продолжит поддерживать реформы и региональное сотрудничество на Балканах» (Ambassador MacLeod: Britain's policy ... , 2019: Электронный ресурс). Напомним, что «заслугой» Лондона на Берлинском конгрессе 1878 г. было недопущение получения Сербией выхода к морю, а Босния и Герцеговина была «подарена» Австро-Венгрии. Лондон первым поддержал план создания общего югославянского государства, не допустив создания расширенной Сербии, как того требовал ее статус государствапобедителя в Первой мировой войне. Британия проявляла большой интерес к экономике и торговле Королевства сербов, хорватов и словенцев (КСХС), одновременно интернационализируя и искусственно раздувая «хорватский вопрос». Все, что к нему относилось, тщательно отслеживалось, поддерживалось и контролировалось Лондоном. Он же оказывал на сербское правительство давление в связи с проведением административно-территориальной реформы в направлении федерализации страны. Создание Хорватской бановины стало 
ее результатом, в границах которой не по своей воли оказалось 1,2 млн сербов, это «плод работы британских политиков и разведчиков» (Миладиновић, 2019: Электронный ресурс).

Когда НАТО проводило военную агрессию против Союзной Республики Югославия, английским премьер-министром был Тони Блэр, крайне непримиримо настроенный к Сербии. В своих мемуарах он признает, что «сыграл ключевую роль в той военной интервенции... был в меньшинстве, когда выступал за военное решение косовского кризиса» (Заборављена пресуда ..., 2014: Электронный ресурс). Известно также следующее его высказывания того периода: «Война против сербов - это больше не только военное столкновение. Это битва между добром и злом, между цивилизацией и варварством» (Најгоре изјаве ..., 2018: Электронный ресурс). В настоящее время частный Институт Тони Блэра (всего в мире у него шестнадцать подобных организаций) оказывает консультационные услуги правительству Сербии, при этом, как подчеркнула сербский премьер Ана Брнабич, из сербского «бюджета на это не выделяется ни динара» (Брнабић: Институт ..., 2019: Электронный ресурс). По ее словам, «это часть некоммерческой деятельности Института... Почему у Института существует подобная некоммерческая деятельность... спросите Институт...» (там же). У Брнабич есть вполне ясный личный мотив для благодарности Блэру: она появилась во властных коридорах Сербии из небытия именно в период создания по совету Блера рабочих групп, в состав одной из которых вошла будущий премьер. Причем в собственном правительстве Блэр подобные группы быстро ликвидировал, оставив их в наследство странам глубокой периферии как средство параллельного внезаконного контроля и управления. Одновременно Блэр является советником правительства Албании и «близким другом» косовских албанцев. Кроме того, при советнике Блэре была реализована инициатива прохождения обучения в Великобритании 6 тыс. государственных служащих Сербии, что, по мнению сербского исследователя Синиши Лепоевича, является ничем иным, как созданием «британской агентурной сети внутри сербского государственного аппарата» (Љепојевић, 2019: Электронный ресурс). Таким образом, следует неутешительный вывод, что единство интересов, целей и действий возможно исключительно между равными и равноправными партнерами. Отношение Великобритании к Сербии является наиболее непримиримым и носит ассиметричный патрон-клиентистский характер. Правительство Сербии придерживается курса «безальтернативности ЕС» под прямым контролем высших представителей британского политического истеблишмента, что указывает на процесс управляемой десуверенизации страны под прикрытием неясной «европейской интеграции». В связи с этим неудивительно, что за прошедшие годы евроинтеграционный процесс 
воспринимается сербским обществом с отчетливым раздражением от непонимания происходящего и затянувшегося «холостого хода».

\section{ЗАПАДНЫЕ БАЛКАНЫ И \\ ПЕРСПЕКТИВА РАСШИРЕНИЯ ЕС}

Как отмечают авторы аналитического доклада «Глобальная стратегия безопасности ЕС 2016», в обоих документах о европейской безопасности (2003 и 2016 гг.) есть упоминания о Западных Балканах. Но «тональность упоминаний региона за 13 лет претерпела изменение. В документе 2003 г. Балканы ассоциируются с нестабильностью и относятся к угрозам европейской безопасности. Стратегической целью для региона, где “вспышка конфликта наглядно напомнила о том, что война не исчезла с нашего континента", является его “европейская перспектива”» (Глобальная стратегия ..., 2017: 28). В документе 2016 г. уже прослеживается взимоисключающие оценки: с одной стороны, «политика расширения на Балканах в целом признается успешной. Она названа “незаменимым инструментом” обеспечения безопасности стран ЕС» (там же). С другой стороны, признается, что «ни конфликт вокруг статуса Косово, ни проблема существования единой Боснии и Герцеговины до сих пор не разрешены, и в условиях нарастающей в последние годы нестабильности в регионе (внутриполитическим кризисом охвачены также Македония, Черногория и Албания) Западные Балканы могут вновь превратиться в источник серьезных потрясений для европейской системы безопасности» (там же: 29). В Стратегии расширения ЕС (февраль 2018 г.) и Солоникской декларации (май 2018 г.) ясно выражена концепция о том, что расширение Евросоюза возможно лишь после его реформирования. Хотя тревожным сигналом для стран, стремящихся вступить в ЕС, должна была послужить отмена функции комиссара по расширению Евросоюза еще в 2014 г.

На настоящем этапе за полную блокаду евроинтеграции выступает взявший курс на лидерство в ЕС в условиях выхода Британии Эммануэль Макрон. Он заявляет о прекращении расширения ЕС до фундаментального реформирования, предлагает изменить методологию переговоров о расширении. Со стороны брюссельской бюрократии поступают более чем ясные сигналы. Так, например, вице-президент Европарламента Ульрике Луначек 12 ноября 2016 г. заявила: «...ни одной стране Западных Балкан не может быть обещано, что она будет принята в Европейский союз, даже если для этого она выполнит все условия...» (Албуновић, 2016: Электронный ресурс). В ходе Всемирного экономического форума в Давосе в конце января 2018 г. французский президент Э. Макрон отметил, что «Европа должна найти новые амбиции. Я не наивен. Мы никогда больше не построим ничего похожего на то, чем была амбиция двадцати семи. Идея заключается в том, что Франция, Германия и северная 
Европа перестроятся. Те, кто более амбициозен, должны двинуться к сближению» (цит. по: Самарџић, 2018: Электронный ресурс). В обращении к депутатам Европейского парламента в Страсбурге 17 апреля 2018 г. Макрон заявил, что стремится «скрепить Западные Балканы европейским проектом, однако сейчас не время для приема новых членов...» и поддержит «расширение, только если сначала пройдет углубление и реформирование нашей Европы», отметив, что он «не желает поворота Балкан к Турции или России, но и не хочет, чтобы Европа, которая тяжело справляется с 28-ю, а завтра с 27-ю членами, решится на принятие новых членов по старым правилам» (Makron: EU ne treba ..., 2018: Электронный ресурс). Он предостерегает от каких бы то ни было попыток обойти запрет Франции. На заключительной конференции НАТО в Лондоне (начало декабря 2019 г.) он еще раз более чем четко выразился, чтобы «сначала прошла реформа процедуры переговоров, а только потом следующее продвижение переговоров» (цит. по: Maksimović, 2019: Электронный ресурс). Относительно «Западных Балкан», согласно заявлению главы европейской дипломатии Жозепа Борреля от 27 января 2020 г., остается лишь «общее видение, как достичь стабильности и безопасности в этом важном регионе...» Евросоюз: У нас есть общее ..., 2020: Электронный ресурс). Пока оно заключается в стремлении не оставить за Евросоюзом «вакуум, который потом заполняют другие страны», при этом «более активную роль в построении такой Европы, которая развивала бы еще более эффективную совместную внешнюю политику и политику безопасности» следует взять на себя Германии (там же). На настоящий момент можно утверждать, что Евросоюз не только не приступил к своему реформированию, но нет даже внятных проектов реформ. Следовательно, Евросоюз с приемом в свои ряды Хорватии в 2013 г. с процессом интеграции пришел к своему историческому финалу. Для стран, провозгласивших вступление в ЕС своей единственной стратегической целью во внешней политике, это более чем серьезный повод для открытия общественного диалога по широкому спектру региональных вопросов и переосмысления внешнеполитических задач.

\section{ЗАКЛЮЧЕНИЕ}

Для Сербии отсутствие реальной перспективы евроинтеграции равно крупнейшему внешнеполитическому провалу. Однако нынешняя власть предпочитает неудачу выдать за приверженность принципу, на данный момент подчеркивается, что «ЕС по-прежнему нет альтернативы», и «Сербия только таким образом может провести внутренние реформы, даже если и не станет членом ЕС» (Самарџић, 2019: Электронный ресурс). Однако внутренние реформы так и не были проведены, Сербия превратилась в периферийную экономически отсталую страну с режимом авторитарной личной власти, мощной 
депопуляции и крайней степени коррупции. Сербию покидает все больше молодежи, в подавляющем большинстве она уезжает на заработки в Германию. Там требуются в основном рабочие профессии - автомеханики, слесари, санитарки, но высок запрос и на престижные профессии - врачей, IT-специалистов и т. д. Евросоюз, со своей стороны, пытается справиться с внутренними системными противоречиями, в среднесрочной перспективе он вероятнее всего продолжит свое существование как весьма турбулентное, но единое и закрытое образование. «Риторика о продвижении демократии» и «идея целостного пространства европейского соседства» (Глобальная стратегия ... , 2017: 4) применительно к Сербии больше не используются. На смену пришли новые принципы, на основе которых планируется строить взаимоотношения, а именно - повышение «устойчивости» и применение «принципиального прагматизма» (там же). Несмотря на определенную гибкость этих понятий, очевидно, что Евросоюз, продолжая применять ценностно-ориентированный подход с тенденцией к установлению монополии на реализацию собственных интересов в большинстве сфер международной деятельности, в среднесрочной перспективе намерен сохранить статус-кво в отношении стремящихся к интеграции с ним «западнобалканских государств».

\section{СПИСОК ЛИТЕРАТУРЫ}

Бископ, С. (2009) Основы обновленной Европейской стратегии безопасности [Электронный ресурс] // Вестник международных организаций. Т. 4. № 2 (24). C. 105-120. URL: https://iorj.hse.ru/data/2011/01/21/1208902255/European Security.pdf [архивировано в WaybackMachine] (дата обращения: 10.02.2020).

Глобальная стратегия безопасности ЕС 2016 (2017) : аналитический доклад / под ред. Н. К. Арбатовой, А. М. Кокеева. М. : ИМЭМО РАН. Режим доступа: https://www.imemo.ru/index.php?page $\mathrm{id}=645 \& \mathrm{id}=3850$ [архивировано в WaybackMachine] (дата обращения: 10.02.2020). DOI: 10.20542/978-5-95350505-5

Гулевич, В. (2019) Аахенское соглашение Германии и Франции [Электронный ресурс] // Фонд стратегической культуры. 5 февраля. URL: https:// www.fondsk.ru/news/2019/02/05/aahenskoe-soglashenie-germanii-i-francii-47552. $\underline{\mathrm{html}}$ [архивировано в WaybackMachine] (дата обращения: 10.02.2020).

Евросоюз: У нас есть общее видение будущего Западных Балкан (2020) [Электронный ресурс] // EADaily. 27 января. URL: https://eadaily.com/ru/news/ 2020/01/27/evrosoyuz-u-nas-est-obshchee-videnie-budushchego-zapadnyh-balkan [архивировано в WaybackMachine] (дата обращения: 10.02.2020).

Толстухина, А. (2016) «Европейский Союз в поиске глобальной роли: политика, экономика, безопасность» [Электронный ресурс] // Международная 
жизнь. 4 октября. URL: https://interaffairs.ru/news/show/16088 [архивировано в WaybackMachine] (дата обращения: 10.02.2020).

Албуновић, М. (2016) Луначек: Ни једној држави Западног Балкана не може се обећати чланство у ЕУ [Электронный ресурс] // Политика. 12 ноября. URL: http://www.politika.rs/sr/clanak/367714/Lunacek-Ni-jednoj-drzavi-Zapadno g-Balkana-ne-moze-se-obecati-clanstvo-u-EU [архивировано в WaybackMachine] (дата обращения: 10.02.2020).

Брнабић: Институт Тонија Блера саветује Владу Србије «про боно» (2019) [Электронный ресурс] // Вечерње новости. 27 февраля. URL: https://www.novosti. rs/вести/насловна/политика.393.html:779917-Brnabic-Institut-Tonija-Blera-savetuje-Vladu-Srbije-pro-bono [архивировано в WaybackMachine] (дата обращения: 10.02.2020).

Заборављена пресуда: Зашто није ухапшен Тони Блер због бомбардовања? (2014) [Электронный ресурс] // Срби на окуп! 21 июня. URL: http:// srbinaokup.info/?p=41380 [архивировано в WaybackMachine] (дата обращения: 10.02.2020).

Јовановић, М. (2009) Србија и ЕУ: вечно чекање на бар 1918 препрека [Электронный ресурс] // Nova srpska politička misao. 18 ноября. URL: http:// www.nspm.rs/ekonomska-politika/srbija-i-eu-vecno-cekanje-na-bar-1918-preprek a.html [архивировано в WaybackMachine] (дата обращения: 10.02.2020).

Јовановић, М. (2013) ЕУ је била лепа док је трајала [Электронный ресурс] // Нова српска политичка мисао. 10 мая. URL: http://www.nspm.rs/ politicki-zivot/eu-je-bila-lepa-dok-je-trajala.html [архивировано в WaybackMachine] (дата обращения: 10.02.2020).

Јовановић, М. (2018) Српски пут у ЕУ-топију [Электронный ресурс] // Нова српска политичка мисао. 13 января. URL: http://www.nspm.rs/kuda-idesrbija/srpski-put-u-eu-topiju.html [архивировано в WaybackMachine] (дата обращения: 10.02.2020).

Љепојевић, С. (2019) Зашто Блер и Британци саветују Владу Србије? [Электронный ресурс] // Искра. 9 марта. URL: https://iskra.co/reagovanja/sinisaljepojevic-zasto-bler-i-britanci-savetuju-vladu-srbije/ [архивировано в Wayback Machine] (дата обращения: 10.02.2020).

Миладиновић, И. (2019) Сусрет са историјом: Србофобија Енглеза дуга готово два века [Электронный ресурс] // Вечерње новости. 24 февраля. URL: https://www.novosti.rs/вести/насловна/репортаже.409.html:779169-SUSRET-S A-ISTORIJOM-Srbofobija-Engleza-duga-gotovo-dva-veka [архивировано в WaybackMachine] (дата обращения: 10.02.2020).

Најгоре изјаве западних званичника у време бомбардовања Србије (2018) [Электронный pecypc] // Gеополитика.ru. 24 марта. URL: https://www. 
geopolitica.ru/sr/article/najgore-izjave-zapadnih-zvanichnika-u-vreme-bombardovanja-srbije [архивировано в WaybackMachine] (дата обращения: 10.02.2020).

Први споразум о принципима који регулишу нормализацију односа (2013) [Электронный ресурс] // Канцеларија за Косово и Метохију. Влада Републике Србије. URL: http://www.kim.gov.rs/p03.php [архивировано в WaybackMachine] (дата обращения: 10.02.2020).

Самарџић, С. (2018) Србија је данас даље од ЕУ него што је била 2003 [Электронный ресурс] // Србија и свет. 21 апреля. URL: https://srbijasvet.word press.com/2018/04/21/србија-је-данас-даље-од-еу-него-што-је-б/ [архивировано в WaybackMachine] (дата обращения: 10.02.2020).

Самарџић, С. (2019) Србија се мора извући из «западнобалканског» логора [Электронный ресурс] // Краљевски књижевни клуб «Караџорђевић». 12 июня. URL: http://kkkkaradjordjevic.blogspot.com/2019/06/blog-post.html [архивировано в WaybackMachine] (дата обращения: 10.02.2020).

Jovanović, M. (2007) Bar 1918. prepreka na putu Srbije ka članstvu u EU [Электронный ресурc] // Nova srpska politička misao. 17 декабря. URL: http:// www.miroslavjovanovic.com/images/clanci/Bar-1918-prepreka-Srbije-ka-clanstvu -EU-12.11.07-M-Jovanovic.pdf [архивировано в WaybackMachine] (дата обращения: 10.02.2020).

Makron: EU ne treba da prima nove članice (2018) [Электронный ресурс] // Kurir. 17 апреля. URL: https://www.kurir.rs/vesti/politika/3032345/makron-eu-netreba-da-prima-nove-clanice [архивировано в WaybackMachine] (дата обращения: 10.02.2020).

Maksimović, M. (2019) Zapadni Balkan između Brisela i Pariza [Электронный ресурс] // DW. 5 декабря. URL: https://www.dw.com/sr/zapadni-balkanizmeđu-brisela-i-pariza/a-51539075 [архивировано в WaybackMachine] (дата обращения: 10.02.2020).

Ambassador MacLeod: Britain's policy on the Balkans to remain the same (2019) [Электронный ресурс] // Briefing. 31 октября. URL: https://betabriefing. com/archive/news/8757-ambassador-macleod-britains-policy-on-the-balkans-to-remain-the-same [архивировано в WaybackMachine] (дата обращения: 10.02. 2020).

Дата поступления: 20.02.2020 2.

\section{REFERENCES}

Biskop, S. (2009) Osnovy obnovlennoi Evropeiskoi strategii bezopasnosti [Framework of the renewed European Security Strategy]. Vestnik mezhdunarodnykh organizatsii, vol. 4, no. 2 (24), pp. 105-120. Available at: https://iorj.hse.ru/ 
data/2011/01/21/1208902255/European_Security.pdf [archived in WaybackMachine] (accessed 10.02.2020). (In Russ.).

Global'naia strategiia bezopasnosti ES 2016 [Global Security Strategy of the EU 2016] (2017) : An analytical report / ed. by N. K. Arbatova and A. M. Kokeev. Moscow : Institute of World Economy and International Relations RAS. Available

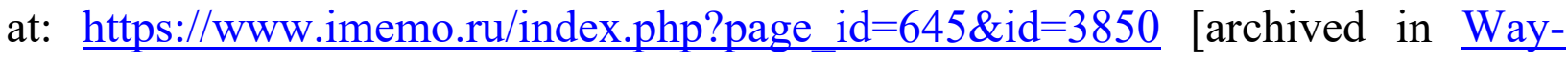
backMachine] (accessed 10.02.2020). (In Russ.). DOI: 10.20542/978-5-9535-0505$\underline{5}$

Gulevich, V. (2019) Aakhenskoe soglashenie Germanii i Frantsii [FrancoGerman Aachen Treaty]. Fond strategicheskoi kul'tury, February 5. Available at: https://www.fondsk.ru/news/2019/02/05/aahenskoe-soglashenie-germanii-i-francii47552.html [archived in WaybackMachine] (accessed 10.02.2020). (In Russ.).

Evrosoiuz: U nas est' obshchee videnie budushchego Zapadnykh Balkan [European Union: We have a general view on the future of the Western Balkans] (2020) EADaily, January 27. Available at: https:/eadaily.com/ru/news/2020/01/27/evrosoyuz-u-nas-est-obshchee-videnie-budushchego-zapadnyh-balkan [archived in WaybackMachine] (accessed 10.02.2020). (In Russ.).

Tolstukhina, A. (2016) «Evropeiskii Soiuz v poiske global'noi roli: politika, ekonomika, bezopasnost'» ["European Union in search for a global role: Politics, economics, security"]. Mezhdunarodnaia zhizn', October 4. Available at: https://interaffairs.ru/news/show/16088 [archived in WaybackMachine] (accessed 10.02. 2020). (In Russ.).

Albunović, M. (2016) Lunacek: Ni jednoj drzhavi Zapadnog Balkana ne mozhe se obecati chlanstvo u EU [Lunacek: No country of the Western Balkans can be promised EU membership]. Politika, November 12. Available at: http://www.politika.rs/sr/clanak/367714/Lunacek-Ni-jednoj-drzavi-Zapadnog-Balkana-ne-moze-se-obecati-clanstvo-u-EU [archived in WaybackMachine] (accessed 10.02.2020). (In Serb.).

Brnabić: Institut Tonija Blera savetuje Vladu Srbije «pro bono» [Brnabić: Tony Blair Institute advises the Government of Serbia "pro bono"] (2019) Vechernje novosti, February 27. Available at: https://www.novosti.rs/вести/насловна/политика.393.html:779917-Brnabic-Institut-Tonija-Blera-savetuje-Vladu-Srbije-pro-bono [archived in WaybackMachine] (accessed 10.02.2020). (In Serb.).

Zaboravljena presuda: Zashto nije ukhapshen Toni Bler zbog bombardovanja? [Forgotten verdict: Why wasn't Tony Blair arrested for the bombing?] (2014) Srbi na okup! June 21. Available at: http://srbinaokup.info/?p=41380 [archived in WaybackMachine] (accessed 10.02.2020). (In Serb.).

Jovanović, M. (2009) Srbija i EU: vechno chekanje na bar 1918 prepreka [Serbia and the EU: Eternal waiting for at least 1918 obstacles]. Nova srpska politička misao, November 18. Available at: http://www.nspm.rs/ekonomska-politika/srbija- 
i-eu-vecno-cekanje-na-bar-1918-prepreka.html [archived in WaybackMachine] (accessed 10.02.2020). (In Serb.).

Jovanović, M. (2013) EU je bila lepa dok je trajala [The EU was good while it lasted]. Nova srpska politichka misao, May 10. Available at: http://www.nspm.rs/politicki-zivot/eu-je-bila-lepa-dok-je-trajala.html [archived in WaybackMachine] (accessed 10.02.2020). (In Serb.).

Jovanović, M. (2018) Srpski put u EU-topiju [The Serbian path to the EU utopia]. Nova srpska politichka misao, January 13. Available at: http://www.nspm. rs/kuda-ide-srbija/srpski-put-u-eu-topiju.html [archived in WaybackMachine] (accessed 10.02.2020). (In Serb.).

Ljepojević, S. (2019) Zashto Bler i Britantsi savetuju Vladu Srbije? [Why are Blair and the British advising the Serbian government]. Iskra, March 9. Available at: https://iskra.co/reagovanja/sinisa-ljepojevic-zasto-bler-i-britanci-savetuju-vladu -srbije/ [archived in WaybackMachine] (accessed 10.02.2020). (In Serb.).

Miladinović, I. (2019) Susret sa istorijom: Srbofobija Engleza duga gotovo dva veka [Meeting with history: English Serbophobia lasts for almost two centuries]. Vechernje novosti, February 24. Available at: https://www.novosti.rs/вести/ насловна/репортаже.409.html:779169-SUSRET-SA-ISTORIJOM-Srbofobija-Engleza-duga-gotovo-dva-veka [archived in WaybackMachine] (accessed 10.02. 2020). (In Serb.).

Najgore izjave zapadnikh zvanichnika u vreme bombardovaњa Srbije [The worst statements made by Western officials during the bombing of Serbia] (2018) Geopolitika.ru, March 24. Available at: https://www.geopolitica.ru/sr/article/ najgore-izjave-zapadnih-zvanichnika-u-vreme-bombardovanja-srbije [archived in WaybackMachine] (accessed 10.02.2020). (In Serb.).

Prvi sporazum o printsipima koji regulishu normalizatsiju odnosa [The first agreement on the principles of regulation and normalization of relations] (2013) Kantselarija za Kosovo i Metokhiju. Vlada Republike Srbije. Available at: http://www.kim.gov.rs/p03.php [archived in WaybackMachine] (accessed 10.02. 2020). (In Serb.).

Samardžić, S. (2018) Srbija je danas daљe od EU nego shto je bila 2003 [Serbia is now even further from the EU than it was in 2003]. Srbija i svet. April 21. Available at: https://srbijasvet.wordpress.com/2018/04/21/србија-је-данас-даљеод-еу-него-што-је-б/ [archived in WaybackMachine] (accessed 10.02.2020). (In Serb.).

Samardžić, S. (2019) Srbija se mora izvući iz «zapadnobalkanskog» logora [Serbia must break out of the Western Balkan camp]. Krasevski knjizhevni klub «Karauorheviћ», June 12. Available at: http://kkkkaradjordjevic.blogspot.com/ 2019/06/blog-post.html [archived in WaybackMachine] (accessed 10.02.2020). (In Serb.). 
Jovanović, M. (2007) Bar 1918. prepreka na putu Srbije ka članstvu u EU [At least 1918 obstacles in Serbia's path to the EU]. Nova srpska politicka misao, December 17. Available at: http://www.miroslavjovanovic.com/images/clanci/Bar1918-prepreka-Srbije-ka-clanstvu-EU-12.11.07-M-Jovanovic.pdf [archived in Way backMachine] (accessed 10.02.2020). (In Serb.).

Makron: EU ne treba da prima nove članice [Macron: EU should not accept new members] (2018) Kurir, April 17. Available at: https://www.kurir.rs/vesti/politika/3032345/makron-eu-ne-treba-da-prima-nove-clanice [archived in Wayback Machine] (accessed 10.02.2020). (In Serb.).

Maksimović, M. (2019) Zapadni Balkan između Brisela i Pariza [Western Balkans between Brussels and Paris]. DW, December 5. Available at: https:// www.dw.com/sr/zapadni-balkan-između-brisela-i-pariza/a-51539075 [archived in WaybackMachine] (accessed 10.02.2020). (In Serb.).

Ambassador MacLeod: Britain's policy on the Balkans to remain the same (2019) Briefing, October 31. Available at: https://betabriefing.com/archive/news/ 8757-ambassador-macleod-britains-policy-on-the-balkans-to-remain-the-same [archived in WaybackMachine] (accessed 10.02.2020).

Submission date: 20.02.2020.

Филимонова Анна Игоревна - кандидат исторических наук, доцент кафедры международных отношений и дипломатии факультета международных отношений и туризма Московского гуманитарного университета. Адрес: 111395, г. Москва, ул. Юности, 5, корп. В, каб. 208. Тел.: +7 (499) 374-92-10. Эл. адрес: annafilimon@yandex.ru

Filimonova Anna Igorevna, Candidate of History, Associate Professor, Department of Foreign Relations and Diplomacy, Faculty of International Relations and Tourism, Moscow University for the Humanities. Postal address: Office 208, Bldg. B, 5 Yunosti St., 111395 Moscow, Russian Federation. Tel.: +7 (499) 374-9210. E-mail: annafilimon@yandex.ru

\section{Для циитирования:}

Филимонова А. И. Ключевые проблемы евроинтеграции Сербии на современном этапе [Электронный ресурс] // Горизонты гуманитарного знания. 2020. № 2. C. 58-76. URL: http://journals.mosgu.ru/ggz/article/view/1194 (дата обращения: дд.мм.гггг). DOI: 10.17805/ggz.2020.2.4 